\title{
Profitability Development of Dairy Farms in Slovenia
}

\author{
Nikolche Jankulovski ${ }^{1}$, Katerina Bojkovska ${ }^{1}$, Goran Mihajlovski ${ }^{1}$ \& Angelka Jankulovska ${ }^{1}$ \\ ${ }^{1}$ University St. Kliment Ohridski, Bitola, Republic of N. Macedonia \\ Correspondence: Nikolche Jankulovski, University St. Kliment Ohridski, Bitola, Republic of N. Macedonia. \\ E-mail: nikolce.jankulovski@uklo.edu.mk
}

Received: July 27, 2020

doi:10.5539/jas.v12n11p150
Accepted: September 27, $2020 \quad$ Online Published: October 15, 2020

URL: https://doi.org/10.5539/jas.v12n11p150

\begin{abstract}
The importance of the dairy industry for the regional and national economy is essential. This paper highlights the financial performance and profitable development of dairy farms in Slovenia by examining milk production. In this study, the correlation of variables representing the number of cows, forage area and milk production were found to be very strong with values of $\mathrm{R}=0.85 ; \mathrm{R}-0.95 ; \mathrm{R}=0.79$. The farm size has an impact on cost ratios, liquidity, return on assets, and debt. The interactions of these significant factors are evaluated as return on investments.
\end{abstract}

Keywords: desirability, farmstead, return on total assets, Slovenia

\section{Introduction}

Since 1961 the growth rate of global food production has increased by $170 \%$. This growth emerged from improving agricultural produce by breeding, application of pesticides, synthetic fertilizers, and the cultivation of high yielding crops, monocultures, and intensive tillage with an effective mechanism. This conventional farming method incurs environmental costs and affects farmland due to the loss of organic matter, soil erosion, eutrophication, and water pollution by loss of biodiversity (Kurz, 2018). Implementing organic farming and a self-regulating agricultural unit helps to minimize the adverse effects of agriculture on the ecosystem, it will also enunciate environmental sustainability for the long term.

Numerous studies have demonstrated the advantages of organic farming to soil structure, microbial diversity, and organic matter that support long term soil productivity. Organic farming mitigates low pollutions on terrestrial and aquatic ecosystems and improves biodiversity (Kurz, 2018); it is a sustainable agricultural approach that focuses on utilizing biological fertilizers and ecologically based pest controls, instead of chemical-based fertilizers. More healthy crops are produced with Organic agriculture, with little or no adverse effect on the environment (Madhusudhan, 2016). Besides these, the dairy industry has flourished globally, been of tremendous value to economies; however, most of the milk produced is not exported to other countries. The European economic and social committee stated that $8 \%$ of dairy productions are traded globally. A sm all change in global production will affect the world market; two percent difference between worldwide consumption and production rate equals $25 \%$ of the world dairy market (Zakova Kroupova, 2016). The global economic growth indicator doesn't solely depend on the performance of international agricultural trade. Based on the data gathered by this report, a change in profitability was positive for the period under review. The technical shift in output price and mark up component are significant indicators for profitability. The main aim of this research paper is to evaluate the profitable development of dairy farms in Slovenia.

\subsection{Empirical Review}

Berkum (2007) analyzed the dairy chain in Slovenia and highlighted some roadblocks to profitability in the industry. Firstly, is the loss in market share to competitors in the international market due to increasing unmet demands for milk and the establishment of unfavorable policies in the region. Muminović \& Pavlović also evaluated the dairy industry's profitability compared to Slovenia, Serbia, and Croatia (Muminović \& Pavlović, 2012). The authors' primarily identified the requirements of the EU for membership as a challenge.

The EU's assertion affects the communication between the farmers and the industry and increases the international market (Muminović \& Pavlović, 2012). Nevertheless, the Serbia dairy market is more profitable than Slovenia and Croatia despite that the countries share similar challenges in the industry. A careful study of the Serbia dairy industry showed that the state maintains profit in the industry due to its low cost of production, 
high retail prices, and a lack of registration with the EU legislation regarding competition and free-market (Muminović \& Pavlović, 2012).

In the first four years of joining the EU (2004-2007), Slovenia lost $35 \mathrm{ml}$ and dropped its human capacity by $20 \%$. Also, the milk quota systems and the EU policy of Common Agricultural Policy have not helped the Slovenia dairy reduce production cost (Muminović \& Pavlović, 2012).

\subsection{Dairy Industry in Slovenia}

The private sector in Slovenia has been in control of the dairy industry since after independence in 1991. Some state farms were in existence, but their numbers were insignificant. Currently, the private sector is the sole producer of milk in Slovenia. Not until 2005, milk production and sales had been below $80 \%$, a non-commercial quantity.

However, since Slovenia is a part of the European Union, the country receives its quota of milk production from the EU milk quota system, which further regulated the country's number of dairy farms. Low producing farms could not get any allocation to continue the production of milk.

There are currently seven milk production and processing companies in the country, including Ljubljanske mlekarne, Mariborske mlekarne, Mlekarna Celeia, Pomurske mlekarne, Gorenjska mlekarna, Mlekarna Ptuj, and Mlekopromet. Ljubljanske Mlekarne is the leading dairy industry in Slovenia. It produces 200 million liters of milk, which indicates $50 \%$ of the country's total purchase of milk. The essential buyers are Pomurskr mlekarne and Mlekarne Celeia in the European Union (Atallah \& ElKtany, 2015). The market leader Ljubljanske mlekarne has $50 \%$ of the market share in Slovenia. Based on the criteria such as operating result, total revenue, and net result, this industry has been graded.

By accepting the fact, the industry employs $30 \%$ of the Slovenian dairy industry employees, so this dairy company has high productivity.

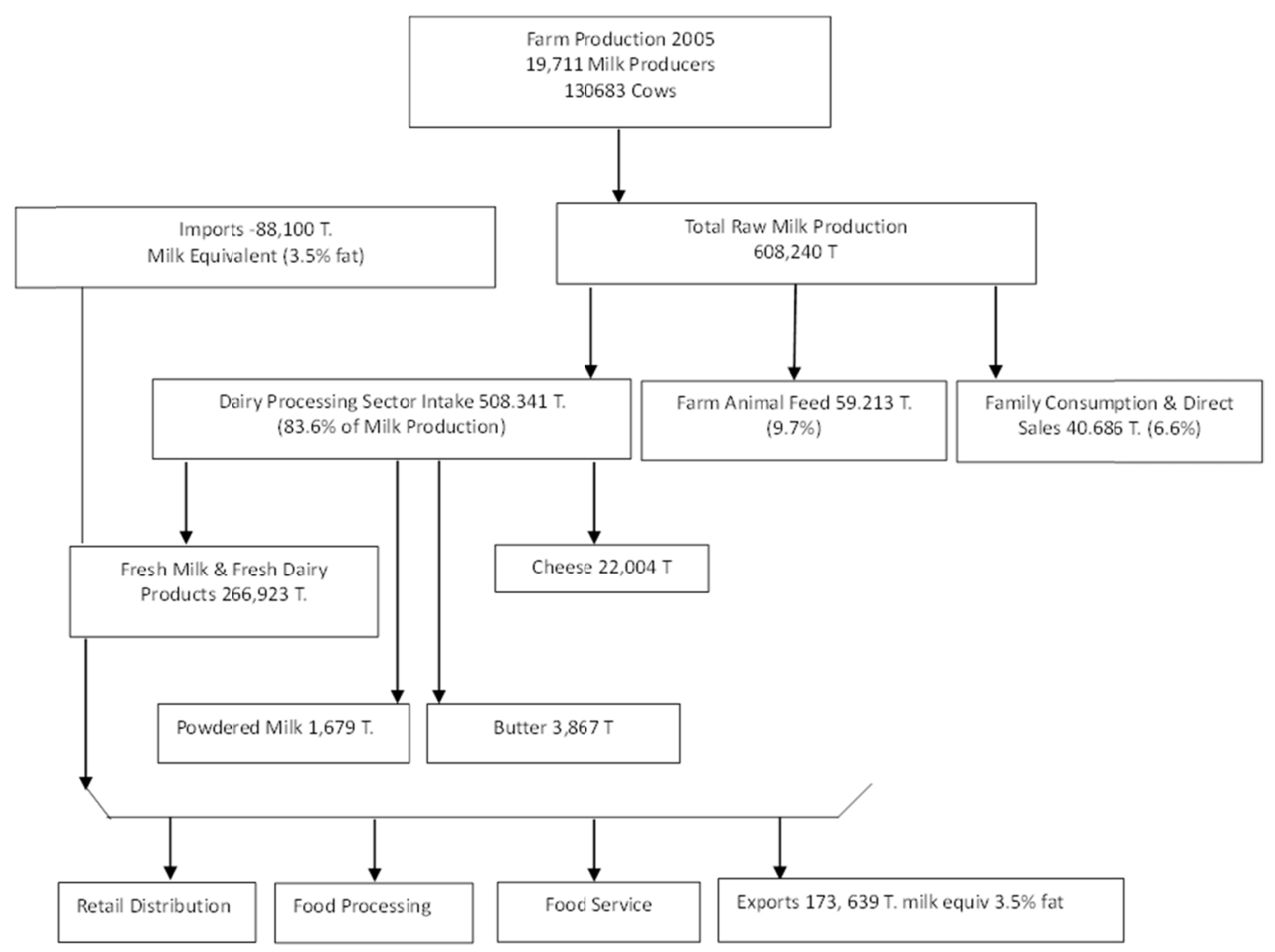

Figure 1. Dairy farm sector in Slovenia

The statistical office of the Republic of Slovenia stated that the quantity of milk collected in Slovenia is decreased by more than $1 \%$ in 2015 compared to 2016. The productions of dairy products in Slovenian dairies had reduced in 2016 comparison to 2015 . In addition to this, the production of drinking milk decreased by $8 \%$. Due to these 
factors, milk production in Slovenia exceeded domestic consumption. There are 125000 dairy cows and yields $6000 \mathrm{~kg}$ per head. Over a decade (1997-2007), the milk yield in Slovenia increased by $50 \%$. Compared to Serbia, sources of funding in Slovenia are the cheapest. The interest rates on term loans varied from $2.5 \%$ to $5.6 \%$ (Bakucs et al., 2013).

\subsection{Performance of the Diary Sector in Slovenia}

\subsubsection{Farm Level}

The dairy farm is mostly operated by small scale farmers with many inefficiencies, averaging 6.6 cows, and 4,500 literss of milk per cow in a year. In 2005, Slovenia was among the least producing European countries alongside Lithuania and Lativa, with 4,200 liters each. At the same time, the Netherlands and Scandinavian countries were the highest producing in the dairy sector. A contributory factor to this low milk yield in Slovenia is the breed of cow predominantly used in the hilly regions. On the one hand, Simmwntal breed of cows is adapted to survive in hilly areas, but their milk production is low. On the other hand, Holstein-Friesian breed of cows produce more milk content, but can't stay in the hilly areas.

Land availability is another challenge the small scale farmer encounter in rearing cows for milk and meat production. Not only is the land hilly, but they are also fragmented in small pieces making usage unproductive for the cows. Therefore, leaving the farmers to travel up to 5 to 8 kilometers to get an arable land for their animals.

\subsubsection{Gross Margin and Turnover}

The gross margin assesses if the dairy farms are making a profit from their sales. The table below compares the gross margin for a different level of farmlands as a competitive element.

Table 1. Gross margin at Slovenian diary farms

\begin{tabular}{ll}
\hline Description & Average Diary Farm (Family farms) \\
\hline Number of cows (LSU) & 6.0 \\
Yield (kg/cow) & 3000 \\
Agricultural holdings & 69,671 \\
\% Holding for consumption & 58 \\
\% Holding for sale & 42 \\
\hline
\end{tabular}

Source: (Krajnc, 2017).

The table shows that there are more family farms in Solvenia than agricultural enterprise farms (231), which sell $100 \%$ of their milk production.

Of the total agricultural holdings, $42 \%$ of products are sold while 585 are for consumption. This shows the limitation of Slovenia milk sales and profitability. 
Table 2. Performance indicators of the dairy industry in the EU

\begin{tabular}{|c|c|c|c|c|c|c|c|}
\hline Countries & $\begin{array}{l}\text { Number of } \\
\text { cows (LU) }\end{array}$ & $\begin{array}{l}\text { Forage } \\
\text { area (ha) }\end{array}$ & $\begin{array}{l}\text { Milk production } \\
(\mathrm{t} / \text { farm })\end{array}$ & $\begin{array}{l}\text { Number of the } \\
\text { employed (AWU) }\end{array}$ & $\begin{array}{l}\text { Milk production } \\
\text { ( } t / \text { ha of forage area) }\end{array}$ & $\begin{array}{l}\text { Milk yield } \\
(\mathrm{kg} \text { per cow) }\end{array}$ & $\begin{array}{l}\text { Labour productivity } \\
\text { (t/AWU) }\end{array}$ \\
\hline Belgium & 58.2 & 46.4 & 406 & 1.8 & 8.8 & 6,989 & 255.6 \\
\hline Denmark & 147.0 & 105.5 & 1,305 & 2.5 & 12.2 & 8,879 & 522 \\
\hline Germany & 56.9 & 105.5 & 436 & 2.1 & 8.3 & 7,674 & 207.6 \\
\hline Spain & 45.4 & 24.4 & 323 & 1.7 & 12.5 & 7,102 & 190 \\
\hline France & 53.8 & 70.9 & 372 & 1.9 & 5.2 & 6,911 & 195.8 \\
\hline Ireland & 61.2 & 56.1 & 329 & 1.6 & 5.9 & 5,369 & 205.6 \\
\hline Italy & 44.8 & 21.4 & 302 & 1.9 & 13.6 & 6.738 & 158.9 \\
\hline Luxembourg & 54.7 & 74.4 & 387 & 1.8 & 5.2 & 7071 & 215.0 \\
\hline Netherlands & 84.5 & 48.5 & 667 & 1.7 & 13.8 & 7,900 & 392.4 \\
\hline Austria & 16.7 & 28.2 & 112 & 1.6 & 4.0 & 6,692 & 70.0 \\
\hline Prtugal & 27.7 & 17.3 & 200 & 1.7 & 11.5 & 7,202 & 117.6 \\
\hline Finland & 29.1 & 37.7 & 252 & 2.0 & 6.7 & 8,683 & 126.0 \\
\hline Sweeden & 65.8 & 90.6 & 567 & 2.2 & 6.3 & 8,619 & 257.7 \\
\hline United Kingdom & 123.2 & 103.6 & 904 & 2.7 & 8.7 & 7,341 & 334.8 \\
\hline Czech Republic & 138.9 & 257.6 & 982 & 15.8 & 3.8 & 7,073 & 62.2 \\
\hline Estonia & 89.8 & 177.7 & 721 & 5.7 & 4. 1 & 8,026 & 126.5 \\
\hline Hungary & 35.9 & 44.0 & 243 & 3.4 & 5.3 & 6,749 & 71.5 \\
\hline Lithuania & 13.1 & 27.2 & 74 & 1.9 & 2.7 & 5,665 & 38.9 \\
\hline Latvia & 13.1 & 27.2 & 74 & 1.9 & 2.7 & 5,665 & 38.9 \\
\hline Malta & 54.2 & 3.9 & 359 & 2.4 & 66.8 & 6,619 & 149.6 \\
\hline Poland & 15.9 & 13.0 & 85 & 1.9 & 6.6 & 5,358 & 44.7 \\
\hline Slovakia & 240.4 & 791.9 & 1,519 & 33.9 & 1.9 & 6,318 & 44.8 \\
\hline Slovenia & 16.4 & 15.3 & 87 & 1.9 & 5.7 & 5,280 & 45.8 \\
\hline Bulgaria & 13.8 & 8.5 & 44 & 2.2 & 4.3 & 3,188 & 20.0 \\
\hline Romania & 3.6 & 2.6 & 12 & 1.1 & 3.6 & 3,405 & 10.9 \\
\hline Croatia & 12.2 & 10.4 & 57 & 2.2 & 5.4 & 4,638 & 25.9 \\
\hline
\end{tabular}

Source: Kuhar (2006).

\section{Material and Method}

Financial statements gathered from the stock exchanges web pages and financial internet database Ibon (Slovenia) informed this study. The non-consolidated financial account also helped to determine the state of dairy companies in Slovenia. The subject of analysis is about consolidating market leaders' financial statements due to their cross border business and size. Consolidated data is used to build a clear picture of the dairy industry in a particular country. The companies employ 1000 persons in Slovenia, so it is an essential industry for local economies (Kurz, 2018). The diary industry covers about $90 \%$ of added value, total assets, EBITDA, and the net result of the dairy industry's segregated companies. The dairy industry representatives in Slovenia are Planika, Ljubljanske Mlrkarne, Mlekarna Celeia, Pomurske mlekarne.

\section{Analysis and Findings}

\subsection{Profitability in Slovenia}

The analysis of dairy plants in Slovenia shows that Slovenia's dairy industry is not an attractive one. The industry did not observe the financial change and profits of joining the European Union; hence, it challenged its profitability. The return on equity measures profit and how equity capital was invested in Slovenia dairy plants.

The accumulated loss of four years was 35 million euros. The number of employees decreased to $20 \%$. This circumstance has been compared with splitting former Yugoslavia (Prišenk, 2016). The difference is that the government did not control the negative influence. After joining the European Union, Slovenia dairy plants experienced tough competition from European Union dairies in milk collection, which led farmers to make agreements with foreign dairies.

Based on the Slovenian Ministry of agriculture, food, and forest statistics, 13.5 thousand tons of milk were sold to Italy in 2016 (Madhusudhan, 2016). Over 160000 tonnes of raw milk was sold to non-Slovenian dairies, equivalent to the total quantity of milk collected from farmers in 2008 and 2009. The result, in turn, affected the 
profitability of the Slovenian dairy industry. Return on assets is the crucial ratio of profitability and represents how company assets are used effectively. The smallest dairy has the least personnel and focuses on achieving profits and prefers financial leverage. Mlekarna Celeia is the only industry to escape the zone of loss; it created an illusion that there was development in big companies' profitability, whereas this profitability remains unsatisfactory. The leading company suffered from a decline in return on assets in 2009 (Figure 2). In 2008, Mlekarna Celeia was the only company that had a loss of 0.6 million.

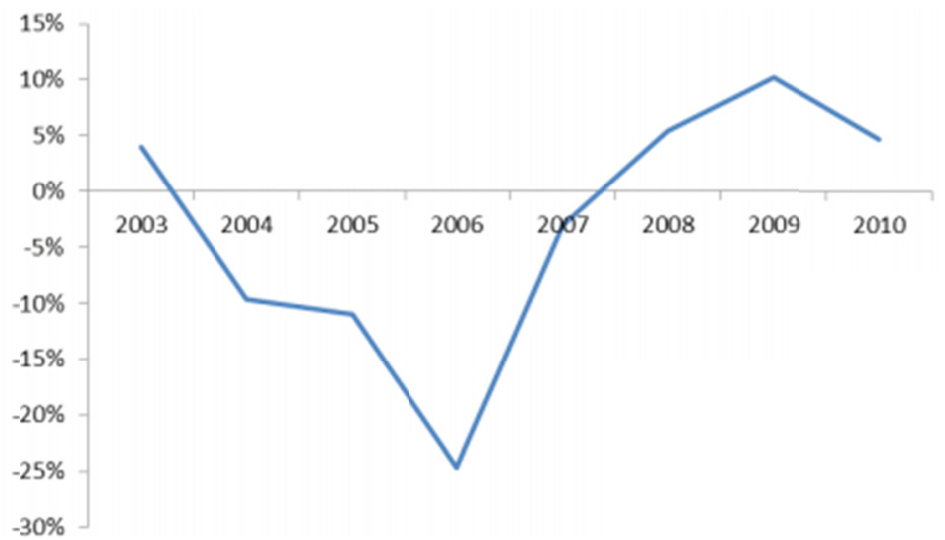

Figure 2. Return on Asset of Slovenian dairy industry

The dairy sector is featured by the small scale production in which two-thirds of dairy farms yield less than 50000 $\mathrm{kg} /$ year. The milk quota of Slovenian is 576k tones, shared among 9300 farmers. Agricultural cooperatives sold most of the milk to dairies; hence, the high number of milk trading cooperatives. Seven dairy companies process milk, and $50 \%$ of the milk is supplied; One-fourth of the milk production goes to Italy, where the milk prices are higher than in Slovenia. At the primary level, milk quality fulfills the high EU standards, and it yields $75 \%$ of the EU average. Compared with average dairy farms in the significant milk-producing countries in EU-15, the gross margins of dairy farms are low in Slovenia (Zakova Kroupova, 2016).

The performance indicators represent declining gross value added per employee and profit figures in the industry. The industry is losing their market shares to foreign competitors. Due to policy changes and market trends, competition in EU markets becomes more intense. The perfect implication for the trends is to find out significant product development and cost reduction by enhancing the scale of operation and investment in marketing the products. The key policy issues are technical and institutional modernization, and land consolidation focused on increasing efficiency, productivity, and rural or regional policy. To support small scale farming, Austria applied a CAP measure to prove Slovenia (Madhusudhan, 2016).

Farms producing milk in the EU are rated by the size of their forage area, milk production, number of cows, and labor inputs. The correlation of these multiple variables showed a strong relationship, given as $\mathrm{R}=0.85 ; \mathrm{R}-0.95$; $\mathrm{R}=0.79$. Which shows the relationship between them as well as the strength of the relationship. The correlation of the data in Table 2 calculated by the formula below showed the correlation as described. Slovenia is among the least nations with good profitability compared with other countries in the EU.

$$
R_{z, x y}=\sqrt{\frac{r_{x z}^{2}+r_{y z}^{2}-2 \cdot r_{x z} \cdot r_{y z} \cdot r_{x y}}{1-r_{x y}^{2}}}
$$

\section{Discussion and Conclusion}

Competitiveness in the Slovenian dairy sector is not active due to small production scale, particularly in the less-favored areas where labor is high and low average yields on these small scale farms due to the type of breed. In addition to this, the land structure needs a land consolidation policy. The milk prices for producers are less than EU producers. The gross margins are low to EU states and large dairy farms. The transport cost from farmers to dairies is essential when the milk payment made through the cooperatives seems to be ineffective.

Dairy processors have lost their strong position just by reducing the performance level and labor productivity concerning market share and value-added services. Dairy processing industries do not have targeted marketing and product specialization. The operating industry is also too small to compete with the international market. It is 
found that the dairy industry in Slovenia is not as profitable as in Croatia and Serbia (Popović \& Panić, 2018). The average profitability of the dairy industry decreased in 2009. According to individual financial statements and consolidated data, Slovenia indicates a high level of ROA.

\section{Policy Recommendations}

The development of government policies has a significant influence on the outcome of the milk processing companies in Slovenia so that the market can overcome all challenges it will encounter at the primary and processing level of the industry. Some areas that government policies will be of significant help to the Slovenia Dairy industry are discussed below:

Land Policies: obtaining arable land for cow grazing has been one of the challenges of small scale farmers. Being that small scale farmer's make more returns than the large scale farmers, the government can promote their activities by creating land transfer policies, especially for the areas with flat land.

Regional policies: this policy is also directed to favor the small scale farmers based in the hilly regions and thus can't breed the Holstein-Friesian breed of cows for more milk production. Austria's regional policy can be adopted in Slovenia since both countries have similar less-favored land areas. Austria implements a variety of measures and programs in the CAP, to compensate for less-favored land areas. Austria's regional policies target small scale farmers in the mountainous regions by providing them direct payments for farming according to environmental protection and nature conservation requirements. Slovenia can adopt this same policy to assist small-scale farmers in the hilly regions.

Research and Modernization policies: there are several activities that the government can take to support Slovenia's farming processes. For instance, providing funds for research purposes in the agricultural sector could bring about a novel approach to breeding cows and milk production. Secondly, researching other international markets could also result in the development of strategic market systems to improve Slovenia milk sales in the global market. Further steps can be taken by the government to ensure market transparency and provide genuine information about Slovenia milk supply and demand. The prices and trade of milk, milk quota, land, and other agricultural inputs in Slovenia.

\section{References}

Atallah, S., \& ElKtany, A. (2015). Some Factors affecting Profitability of Dairy Farms. Alexandria Journal of Veterinary Sciences, 45(1), 119. https://doi.org/10.5455/ajvs.181183

Bakucs, Z., Bojnec, S., Ferto, I., \& Latruffe, L. (2013). Farm size and growth in field crop and dairy farms in France, Hungary, and Slovenia. Spanish Journal of Agricultural Research, 11(4), 869. https://doi.org/ $10.5424 / \mathrm{sjar} / 2013114-3994$

Berkum, S. (2007). Analysis of the dairy chain in Slovenia (1st ed., pp. 3-27). Slovenia.

Banjara, R., \& Paudel, M. (2015). Economic Impact of Organic Farming; Cases from the Farmers of Nepal. Advances in Social Sciences Research Journal, 2(11). https://doi.org/10.14738/assrj.211.1617

Kocjančič, T., Debeljak, M., Žgajnar, J., \& Juvančič, L. (2018 Incorporation of energy into multiple-criteria decision analysis for the sustainable and resilient structure of dairy farms in Slovenia. Agricultural Systems, 164, 71-83. https://doi.org/10.1016/j.agsy.2018.03.005

Kurz, P. (2018). Between Smallholder Traditions and "Ecological Modernisation"-Agricultural Transformation, Landscape Change, and the Cap in Austria 1995-2015. European Countryside, 10(1), 158-179. https://doi.org/ 10.2478/euco-2018-0010

Lupatini, M., Korthals, G., de Hollander, M., Janssens, T., \& Kuramae, E. (2017). Soil Microbiome Is More Heterogeneous in Organic Than in Conventional Farming System. Frontiers in Microbiology, 7. https://doi.org/10.3389/fmicb.2016.02064

Madhusudhan, L. (2016). Organic Farming-Ecofriendly Agriculture. Journal of Ecosystem \& Ecography, 6(3). https://doi.org/10.4172/2157-7625.1000209

Muminović, S., \& Pavlović, V. (2012). Profitability of Dairy Industry in Slovenia, Croatia and Serbia. Pregledni Rad, 62(2), 96-110.

Poczta, W., Średzińska, J., \& Chenczke, M. (2020). Economic Situation of Dairy Farms in Identified Clusters of European Union Countries. Agriculture, 10(4), 92. https://doi.org/10.3390/agriculture 10040092

Popović, R., \& Panić, D. (2018). Technical efficiency of Serbian dairy processing industry. Ekonomika Poljoprivrede, 65(2), 569-581. https://doi.org/10.5937/ekoPolj1802569P 
Prišenk, J. (2016). The economic viability of value-based food chain for dairy farms in mountain regions: An econometric analysis approach. Mljekarstvo, 66(3), 231-238. https://doi.org/10.15567/mljekarstvo. 2016.0308

Zakova Kroupova, Z. (2016). Profitability development of Czech dairy farms. Agricultural Economics, 62(6), 269-279. https://doi.org/10.17221/131/2015-AGRICECON

\section{Copyrights}

Copyright for this article is retained by the author(s), with first publication rights granted to the journal.

This is an open-access article distributed under the terms and conditions of the Creative Commons Attribution license (http://creativecommons.org/licenses/by/4.0/). 